\title{
Perbandingan Metode Term Weighting terhadap Hasil Klasifikasi Teks pada Dataset Terjemahan Kitab Hadis
}

\author{
Ana Tsalitsatun Ni'mah ${ }^{1 *}$, Agus Zainal Arifin ${ }^{2)}$ \\ 1,2) Teknik Informatika, Institut Teknologi Sepuluh Nopember \\ 1) anatsalits@gmail.com, ${ }^{2)}$ agusza@cs.its.ac.id
}

DOI: https://doi.org/10.21107/rekayasa.v13i2.6412

\begin{abstract}
Comparison of a term weighting method for the text classification in Indonesian hadith
ABSTRACT

Hadith is the second source of reference for Islam after the Qur'an. Currently, hadith text is researched in the field of technology for capturing the values of technology knowledge. With the research of the Book of Hadith, retrieval of information from the hadith certainly requires the representation of text into vectors to optimize automatic classification. The classification of the hadith is needed to be able to group the contents of the hadith into several categories. There are several categories in certain Hadiths that are the same as other Hadiths. Shows that there are certain documents of the hadith that have the same topic as other Hadiths. Therefore, a term weighting method is needed that can choose which words should have high or low weights in the Hadith Book space to optimize the classification results in the Hadith Books. This study proposes a comparison of several term weighting methods, namely: Term Frequency Inverse Document Frequency (TF-IDF), Term Frequency Inverse Document Frequency Inverse Class Frequency (TF-IDF-ICF), Term Frequency Inverse Document Frequency Inverse Class Space Density Frequency (TF-IDF$\mathrm{ICS}_{\delta} \mathrm{F}$ ) and Term Frequency Inverse Document Frequency Inverse Class Space Density Frequency Inverse Hadith Space Density Frequency (TF-IDF-ICS $\delta$ F-IHS $\delta$ F). This research compares the term weighting results to the 9 Hadith Book Translation dataset applied to the Naive Bayes classification engine and SVM. 9 Books of Hadith are used, namely: Sahih Bukhari, Sahih Muslim, Abu Dawud, at-Turmudzi, an-Nasa'i, Ibn Majah, Ahmad, Malik, and Darimi. The trial results show that the classification results using the TF-IDF-ICS ${ }_{\delta} \mathrm{F}-\mathrm{IHS} \delta \mathrm{F}$ term weighting method outperformed another term weighting, namely getting a Precession of 90\%, Recall of 93\%, F1-Score of 92\%, and Accuracy of 83\%.
\end{abstract}

Keywords: Term Weighting, Classification, Hadith, TF-IDF, TF-IDF-ICF, TF-IDF-ICS $\delta$ F, TF-IDF-ICS ${ }_{\delta} \mathrm{F}-\mathrm{IHS}_{\delta} \mathrm{F}$.

\section{ABSTRAK}

Hadis adalah sumber rujukan agama Islam kedua setelah Al-Qur'an. Teks Hadis saat ini diteliti dalam bidang teknologi untuk dapat ditangkap nilai-nilai yang terkandung di dalamnya secara pegetahuan teknologi. Dengan adanya penelitian terhadap Kitab Hadis, pengambilan informasi dari Hadis tentunya membutuhkan representasi teks ke dalam vektor untuk mengoptimalkan klasifikasi otomatis. Klasifikasi Hadis diperlukan untuk dapat mengelompokkan isi Hadis menjadi beberapa kategori. Ada beberapa kategori dalam Kitab Hadis tertentu yang sama dengan Kitab Hadis lainnya. Ini menunjukkan bahwa ada beberapa dokumen Kitab Hadis tertentu yang memiliki topik yang sama dengan Kitab Hadis lain. Oleh karena itu, diperlukan metode term weighting yang dapat memilih kata mana yang harus memiliki bobot tinggi atau rendah dalam ruang Kitab Hadis untuk optimalisasi hasil klasifikasi dalam Kitab-kitab Hadis. Penelitian ini mengusulkan sebuah perbandingan beberapa metode term weighting, yaitu: Term Frequency Inverse Document Frequency (TF-IDF), Term Frequency Inverse Document Frequency Inverse Class Frequency (TF-IDF-ICF), Term Frequency Inverse Document Frequency Inverse Class Space Density Frequency (TF-IDF$\mathrm{ICS}_{\delta} \mathrm{F}$ ), dan Term Frequency Inverse Document Frequency Inverse Class Space Density Frequency Inverse Hadith Space Density Frequency (TF-IDF-ICS ${ }_{5} \mathrm{~F}-\mathrm{IHS} \delta \mathrm{F}$ ). Penelitian ini melakukan perbandingan hasil term weighting terhadap dataset Terjemahan 9 Kitab Hadis yang diterapkan pada mesin klasifikasi Naive Bayes dan SVM. 9 Kitab Hadis yang digunakan, yaitu: Sahih Bukhari, Sahih Muslim, Abu Dawud, at-Turmudzi, an-Nasa'i, Ibnu Majah, Ahmad, Malik, dan Darimi. Hasil uji coba menunjukkan bahwa hasil klasifikasi menggunakan metode term weighting TF-IDF-ICS $\delta$ F$\mathrm{IHS}_{\delta} \mathrm{F}$ mengungguli term weighting lainnya, yaitu mendapatkan Precission sebesar $90 \%$, Recall sebesar 93\%, F1Score sebesar 92\%, dan Accuracy sebesar 83\%.

Kata Kunci: Term Weighting, Klasifikasi, Hadis, TF-IDF, TF-IDF-ICF, TF-IDF-ICS $\delta$ F, TF-IDF-ICS ${ }_{\delta}$ F-IHS ${ }_{\delta} F$.

\section{PENDAHULUAN}

Hadis menurut bahasa memiliki arti al-khabar (berita), yaitu sesuatu yang dipercakapkan dan dipindahkan dari seseorang kepada orang lain (Arifin, 2013). Hadis didefinisikan sebagai ucapan, perbuatan, atau penetapan yang disandarkan kepada Nabi Muhammad SAW (Saloot et al., 2016). Hadis dalam KBBI disebut

\section{Article History:}

Received: January, 12 ${ }^{\text {th }}$ 2020; Accepted: May, $10^{\text {th }} 2020$ REKAYASA ISSN: 2502-5325 has been Accredited by Ristekdikti (Arjuna) Decree: No. 23/E/KPT/2019 August $8^{\text {th }}, 2019$ effective until 2023 juga sebagai sunnah yaitu perkataan (sabda), perbuatan, ketetapan, dan persetujuan dari Nabi Muhammad SAW yang dijadikan landasan syariat Islam. Hadis dijadikan sumber hukum Islam selain Al-Qur'an, dalam hal ini kedudukan hadis merupakan sumber hukum kedua setelah Al-Quran.

\section{Cite this as:}

Ni'mah, A.T., \& Arifin, A.Z. (2020). Perbandingan Metode Term Weighting terhadap Hasil Klasifikasi Teks pada Dataset Terjemahan Kitab Hadis. Rekayasa, 13(2), 172-180. https://doi.org/10.21107/rekayasa.v13i2.6412

(c) 2020 Author(s) 
Kitab Hadis adalah kumpulan beberapa dokumen hadis yang disusun oleh mudawwin atau mukharrij (ahli hadis). Kitab Hadis yang paling populer adalah Kitab Hadis Sunni yang terdiri dari 9 Kitab oleh 9 Imam, yaitu (Azmi, AlQabbany, \& Hussain, 2019): Shahih Muslim disusun oleh Muslim (204-262 H), Shahih Bukhari disusun oleh Bukhari (194-256 H), Sunan at-Turmudzi disusun oleh At-Turmudzi (209-279 H), Sunan Abu Dawud disusun oleh Abu Dawud (202-275 H), Sunan Ibnu Majah disusun oleh Ibnu Majah (209-273), Muwatta Malik disusun oleh Imam Malik (93-179 H), Sunan an-Nasa'i disusun oleh an-Nasa'i (215$303 \mathrm{H}$ ), Sunan Darimi disusun oleh Ad-Darimi (181-255 H), dan Musnad Ahmad disusun oleh Imam Ahmad bin Hambal (164-241 H). Setiap Kitab dikategorikan berdasarkan topik yang tertuang di dalam Hadis tersebut (Rostam \& Malim, 2019). Ada beberapa kategori dalam beberapa Kitab Hadis yang sama (Shalat, Iman, IImu, Zakat, Puasa, Thaharah, dII). Hal tersebut menandakan ada beberapa hadis pada Kitab Hadis tertentu memiliki topik yang sama dengan Kitab Hadis lainnya.

Teks Hadis saat ini telah diteliti dalam bidang teknologi untuk dapat ditangkap nilai-nilai yang terkandung di dalam teksnya secara pegetahuan teknologi dengan Natural Language Processing (NLP). Salah satu keuntungan dari menerapkan NLP terhadap teks Hadis adalah implementasi dari sistem cerdas yang dapat menjawab pertanyaan apa pun dengan data dari Hadis, dan dapat membantu masyarakat Muslim dan nonMuslim, untuk memahami Hadis (Saloot et al., 2016). Dengan adanya penelitian terhadap Kitab-kitab Hadis tersebut, pengambilan informasi dari Hadis tentunya membutuhkan representasi teks ke dalam vektor untuk mengoptimalkan tugas mesin klasifikasi otomatis. Secara umum, representasi teks ke vektor dapat diklasifikasikan menjadi dua, yaitu: pengindeksan dan term weighting (Ren \& Sohrab, 2013). Dalam Vector Space Model (VSM), konten teks direpresentasikan sebagai vektor dalam ruang term. Term weighting merupakan proses penghitungan bobot tiap term yang dicari pada setiap dokumen sehingga dapat diketahui ketersediaan dan kemiripan suatu term di dalam dokumen (Sabbah et al., 2017). Term weighting adalah tingkat kepentingan term $t_{i}$ dalam dokumen $d_{j}$.

Term weighting yang paling populer adalah Term Frequency Inverse Document Frequency (TF-IDF) (Ren \& Sohrab, 2013). TF-IDF melakukan pembobotan term pada tiap dokumen dengan memperhatikan kelangkaan term pada keseluruhan dokumen. Hasil akhir dari TF-IDF adalah bobot term pada tiap-tiap dokumen. TF-IDF memberikan bobot tinggi pada term yang jarang muncul pada seluruh dokumen. TF-IDF ini memiliki kekurangan yaitu menghilangan informasi kategori pada tiap dokumen sehingga dilakukanlah penelitian untuk mengembangkan TF-IDF yaitu Term Frequenxy Inverse Document Frequency Inverse Class Frequency (TF-IDF-ICF) yang lebih memperhatikan informasi kategori di dalam melakukan pembobotan term. TFIDF-ICF juga melakukan pembobotan term pada tiap dokumen seperti halnya TF-IDF dengan hasil bobot kata pada tiap dokumen pula. Perbedaannya pada perhitungan ICF, jika IDF hanya memperhitungkan kelangkaan kata pada keseluruhan dokumen, ICF juga menghitung kelangkaan kata pada keseluruhan kelas. Namun, TF-IDF-ICF tidak memperhatikan kepadatan dokumen tiap kelas terhadap munculnya term. Sehingga dikembangkan kembali dengan pendekatan term weighting yaitu Term Frequency Inverse Document Frequency Inverse Class Space Density Frequency (TF-IDF-ICS $\delta$ F) yang lebih memperhatikan kepadatan dokumen pada ruang kelas terhadap munculnya term. Pada kasus Kitab Hadis, dibutuhkan pula pembobotan yang dapat menentukan bobot tinggi dan rendah untuk kepadatan ruang Kitab Hadis. Term weighting yang digunakan untuk mengukur kepadatan ruang Kitab Hadis adalah Term Frequency Inverse Document Frequency Inverse Class Space Density Frequency Inverse Hadith Space Density Frequency (TF-IDF-ICS $\delta$ F- IHS $\delta$ F).

Skema term weighting memainkan peran penting dalam klasifikasi teks. Dibutuhkan suatu metode term weighting yang dapat menghasilkan lebih banyak term yang kaya informasi dan menetapkan nilai bobot term yang sesuai untuk persyaratan klasifikasi teks. Klasifikasi Hadis diperlukan untuk dapat mengelompokkan isi dari hadis tersebut ke 
dalam beberapa kategori. Pada beberapa Kitab Hadis memiliki beberapa kategori yang sama sehingga ada beberapa hadis antar Kitab hadis yang memiliki topik yang sama, oleh sebab itu diperlukan sebuah metode term weighting yang dapat menyeleksi kata mana saja yang harus memiliki bobot tinggi atau rendah pada ruang Kitab Hadis untuk optimasi hasil klasifikasi pada kitab-kitab hadis.

Penelitian ini mengusulkan sebuah perbandingan beberapa metode term weighting yang diterapkan untuk Klasifikasi Terjemahan 9 Kitab Hadis.

\section{METODE}

Beberapa metode term weighting yang akan dibandingkan dan beberapa metode klasifikasi yang digunakan sebagai pembanding di dalam proses uji coba dan evaluasi. Bab yang akan dijelaskan antara lain, yaitu: Preprocessing, TF-IDF, TF-IDF-ICF, TF-IDF$\mathrm{ICS}_{\delta} \mathrm{F}, \mathrm{TF}-\mathrm{IDF}-\mathrm{ICS}{ }_{\delta} \mathrm{F}-\mathrm{IHS} \mathrm{S}_{\delta} \mathrm{F}$, Naive Bayes, dan Support Vector Machine (SVM).

\section{Preprocessing}

Pemrosesan Teks (Text Preprocessing) adalah suatu proses pengubahan bentuk data yang belum terstruktur menjadi data yang terstruktur sesuai dengan kebutuhan untuk proses yang lebih lanjut (Dogan \& Uysal, 2019). Text Preprocessing umumnya terdiri dari case folding, tokenization, filtering dan stemming (Deposit, Shi, \& Jianping, 2018). Masing-masing proses memiliki manfaat terhadap dokumen yang diolah (Uysal \& Gunal, 2014).

Case folding adalah konversi bentuk string menjadi lowercase (Uysal \& Gunal, 2014). Pada case folding bermanfaat dalam proses selanjutnya pada stemming karena pada stemming saat penghapusan imbuhan, dia mengenali karakter huruf besar dan huruf kecil.

Filtering adalah pemfilteran kata-kata yang tidak mengandung makna atau biasa disebut stopword, pada proses filtering kata yang termasuk dalam stopword dihilangkan (Tala, 2003). Langkah ini melakukan penghapusan stopword yang bermanfaat saat proses pembobotan. Karena semakin banyak kata yang tidak mengandung makna yang ikut dalam proses pembobotan, maka akan semakin terganggu hasil bobot yang mewakili setiap dokumen.

Stemming adalah proses yang menyediakan pemetaan variasi kata morfologis yang berbeda ke dalam kata dasar / umum mereka (Tala, 2003). Stemming untuk bahasa Indonesia telah mengalami banyak perkembangan. Pertama kali pengembangan stemming bahasa Indonesia dilakukan oleh Adriani, M dan Nazief, B. pada tahun 1996 dengan diberi nama Confix Stripping Algorithm (Adriani, M., Nazief, B., Asian, J., Tahaghoghi, S. M. M., and Williams, 2007). Algoritma tersebut menggunakan tata bahasa Indonesia di dalam proses penghapusan imbuhan katanya, dengan melakukan pengecekan kebenaran kata dasar pada Kamus Besar Bahasa Indonesia. Selanjutnya algoritma Confix Stripping dikembangkan kembali oleh Arifin, Z.A. dan Setiono, A.N. pada tahun 2002 (Adriani, M., Nazief, B., Asian, J., Tahaghoghi, S. M. M., and Williams, 2007). Algoritma tersebut melakukan pendekatan dengan menghilangkan prefiks terlebih dahulu kemudian suffiks. Algoritma selanjutnya pada pengembangan stemming bahasa Indonesia adalah Porter Indonesian (Tala, 2003). Algoritma ini melakukan proses stemming dengan mengadaptasi algoritma Porter Stemming pada bahasa Inggris. Porter stemming pada bahasa Inggris melakukan penghapusan imbuhan secara sederhana tanpa menggunakan pengecekan terhadap kamus kata dasar. Proses tersebut diadaptasikan terhadap bahasa Indonesia. Algoritma pengembangan stemming bahasa Indonesia adalah Enhanced Confix Stripping (ECS) (Mahendra, 2007). Kemudian algoritma tersebut mengalami pengembangan pada penelitian (Andita Dwiyoga Tahitoe, 2010).

\section{TF-IDF}

Term Frequency Inverse Document Frequency (TF-IDF) adalah salah satu metode pembobotan statistical (Kim \& Gil, 2019). TFIDF mengkalikan term frequency (TF) sebagai penghitung frequency term dalam sebuah dokumen dengan inverse document frequency (IDF) sebagai nilai keinformatifan sebuah term (kelangkaannya pada keseluruhan dokumen). Pengertian Term frequency (TF) adalah setiap kata diasumsikan memiliki kepentingan yang 
proporsional terhadap jumlah kemunculan kata pada dokumen. Inverse Document Frequency (IDF) memperhatikan kemunculan term pada kumpulan dokumen (Dogan \& Uysal, 2019). Fungsi IDF memberikan skor terendah untuk term yang muncul dalam banyak dokumen dalam ruang dokumen $D=$ $d_{1}, d_{2}, d_{3}, \ldots, d_{n}$ (Ren \& Sohrab, 2013). Latar belakang pembobotan ini adalah term yang jarang muncul pada kumpulan dokumen sangat bernilai. Kepentingan tiap term diasumsikan memilki proporsi yang berkebalikan dengan jumlah dokumen yang mengandung term. Term frequency (TF) adalah metode sederhana dari pembobotan kata. Term frequency memperhatikan kemunculan term di dalam dokumen. Bobot tinggi dalam TF-IDF dicapai oleh frekuensi term tinggi (dalam dokumen yang diberikan) dan frekuensi dokumen rendah dari term dalam seluruh kumpulan dokumen, karena itu bobot cenderung menyaring istilah umum. Ketika sebuah istilah muncul di lebih banyak dokumen, rasio di dalam hasil logaritma mendekati 1, mendekatkan IDF dan TF-IDF ke 0 . TF-IDF divisualisasikan dalam Persamaan (1) (Ren \& Sohrab, 2013).

$W_{T F * I D F\left(t_{i}, d_{j}\right)}=t f_{t_{i}, d_{j}} \times\left(1+\log \frac{D}{d f_{\left(t_{i}\right)}}\right)$

dimana, $W_{T F * I D F\left(t_{i}, d_{j}\right)}$ adalah bobot term $i$ pada dokumen $j . t f_{t_{i}, d_{j}}$ adalah jumlah term $i$ di dalam dokumen $j$. $D$ adalah jumlah seluruh dokumen. $d f_{\left(t_{i}\right)}$ adalah jumlah seluruh dokumen yang mengandung term $i$.

\section{TF-IDF-ICF}

TF-IDF tidak memperhatikan persebaran term pada keragaman kelas, hanya berbasis pada dokumen (Ren \& Sohrab, 2013). Kemudian dikembangkanlah TF-IDF menjadi Term Frequency Inverse Document Frequency Inverse Class Frequency (TF-IDF-ICF.) Metode Inverse Class Frequency (ICF) diadopsi dari metode IDF yaitu dengan menggunakan inverse perbandingan jumlah kelas dengan jumlah kelas yang mengandung istilah (Yang, Cai, Leung, Lau, \& Li, 2019). Dalam hal pengindeksan berorientasi kelas, subset dokumen dari ruang dokumen $D=$ $d_{1}, d_{2}, d_{3}, \ldots, d_{n}$ dialokasikan ke kelas tertentu. Sehingga semakin sering istilah muncul dalam dokumen yang ada dalam kelas tersebut, maka bobot istilah semakin mendekati 0 . Fungsi ICF memberikan skor terendah term yang muncul di beberapa kelas di ruang kelas $C=$ $C_{1}, C_{2}, C_{3}, \ldots, C_{n}$. Oleh karena itu, representasi numerik dari suatu term adalah produk dari Term Frequency (parameter lokal), IDF (parameter global), dan ICF (parameter global kategori). Persamaan dari TF-IDF-ICF dapat dilihat pada Persamaan (2) (Ren \& Sohrab, 2013)

$$
\begin{aligned}
W_{T F * I D F * I C F\left(t_{i}, d_{j}, c_{k}\right)} & =t f_{t_{i}, d_{j}} \\
& \times\left(1+\log \frac{D}{d f_{\left(t_{i}\right)}}\right) \\
& \times\left(1+\log \frac{c}{c f_{\left(t_{i}\right)}}\right)
\end{aligned}
$$

dimana, $W_{T F * I D F * I C F\left(t_{i}, d_{j}, c_{k}\right)}$ adalah bobot term $i$ pada dokumen $j . t f_{t_{i}, d_{j}}$ adalah jumlah term $i$ di dalam dokumen $j$. $D$ adalah jumlah seluruh dokumen. $d f_{\left(t_{i}\right)}$ adalah jumlah seluruh dokumen yang mengandung term $i$. $C$ adalah jumlah seluruh kelas. $c f_{\left(t_{i}\right)}$ adalah jumlah kelas yang mengandung term $i$.

\section{TF-IDF-ICS ${ }_{\delta} \mathbf{F}$}

Skema term weighting TF-IDF dan TF-IDF-ICF menekankan pada term yang jarang muncul, yang mendukung tingginya bobot term yang muncul hanya dalam beberapa dokumen dikalikan dengan fungsi IDF dan yang hanya muncul dalam beberapa kelas dikalikan dengan fungsi ICF. Pada $\mathrm{ICS}_{\delta} \mathrm{F}$ menghitung kepadatan dokumen pada ruang kategori berdasarkan setiap term, Inverse Class Space Density Frequency $\left(\mathrm{ICS}_{\delta} \mathrm{F}\right)$ dikalikan dengan TFIDF untuk menghasilkan TF-IDF-ICS $\delta$ F. Karena fungsi ICF memberikan skor terendah untuk istilah-istilah yang muncul di beberapa kelas tanpa memperhatikan tentang ruang kelas, perhitungan $\mathrm{ICS}_{\delta} \mathrm{F}$ kemudian diusulkan. Metode term weighting ini untuk meningkatkan kinerja klasifikasi. Dokumen identik ini yang dikaitkan dengan istilah tertentu mungkin merupakan sub-bagian dari kategori tertentu $c_{k}$. Karena itu, penting untuk mengeksplorasi karakteristik kemunculan istilah dalam ruang dokumen $D=$ $d_{1}, d_{2}, d_{3}, \ldots, d_{n}$ dan kelas ruang. Dalam pengindeksan berorientasi kelas, subset dokumen dari ruang dokumen global dialokasikan ke kelas tertentu $c_{k}(k=1,2, \ldots$, $m)$ sesuai dengan topik mereka. Karena itu, 
ruang kelas didefinisikan sebagai $C=$ $\left\{\left(d_{11}, d_{12}, d_{13}, \ldots, d_{1 n}\right) \quad\right.$ anggota $C_{1}$, $\left(d_{11}, d_{12}, d_{13}, \ldots, d_{1 n}\right) \quad$ anggota $C_{2}$, $\left(d_{m 1}, d_{m 2}, d_{m 3}, \ldots, d_{m n}\right)$ anggota $\left.C_{m}\right\}$ (Ren \& Sohrab, 2013). TF-IDF-ICS $\delta$ F diawali dengan menghitung kepadatan kelasnya $\left(C_{\delta}\right)$ yaitu menghitung dokumen yang mengandung term pada kategori tertentu $\left(c_{k}\right)$, dengan Persamaan (3) (Ren \& Sohrab, 2013).

$C_{\delta}\left(t_{i}\right)=\frac{n_{c_{k}}\left(t_{i}\right)}{N_{c_{k}}}$

dimana, $\quad C_{\delta}\left(t_{i}\right)$ adalah kepadatan kelas terhadap term i. $n_{c_{k}}\left(t_{i}\right)$ adalah jumlah dokumen di dalam kelas $c_{k}$ yang mengandung term $i . N_{c_{k}}$ adalah jumlah keseluruhan dokumen di dalam kelas $c_{k}$.

Kemudian dilanjutkan dengan menghitung kepadatan ruang kelas, yaitu jumlah dari kepadatan keseluruhan kelas yang ada $\left(C S_{\delta}\right)$, dengan persamaan (4) (fuji ren).

$C S_{\delta}\left(t_{i}\right)=\sum_{c_{k}} C_{\delta}\left(t_{i}\right)$

dimana, $C S_{\delta}\left(t_{i}\right)$ adalah kepadatan ruang kelas terhadap term i. $C_{\delta}\left(t_{i}\right)$ adalah kepadatan kelas terhadap term i. $c_{k}$ adalah kelas $(k=1,2, \ldots, m)$. Kemudian hasil dari kepadatan ruang kelas $\left(C S_{\delta}\left(t_{i}\right)\right)$ dilakukan inverse sesuai dengan konsep pada TF-IDF-ICF sebelumnya, dengan persamaan (5) (fuji ren).

$\operatorname{ICS} F\left(t_{i}\right)=\log \left(\frac{C}{C S_{\delta}\left(t_{i}\right)}\right)$

dimana, $I C S_{\delta} F\left(t_{i}\right)$ adalah inverse kepadatan ruang kelas terhadap term $i$. $C$ adalah jumlah keseluruhan kelas. $C S_{\delta}\left(t_{i}\right)$ adalah kepadatan ruang kelas terhadap term $i$. Langkah selanjutnya adalah melakukan perkalian hasil inverse kepadatan ruang kelas terhadap term $i$ $\left(\operatorname{ICS}_{\delta} F\left(t_{i}\right)\right)$ dengan TF-IDF, seperti pada persamaan (6) (fuji ren).

$$
\begin{aligned}
W_{T F * I D F * I C S_{\delta} F\left(t_{i}, d_{j}, c_{k}\right)} & =t f_{t_{i}, d_{j}} \\
& \times\left(1+\log \frac{D}{d f_{\left(t_{i}\right)}}\right) \\
& \times\left(1+\log \frac{c}{C S_{\delta}\left(t_{i}\right)}\right)
\end{aligned}
$$

dimana, $W_{T F * I D F * I C S_{\delta} F\left(t_{i}, d_{j}, c_{k}\right)}$ adalah bobot term $i$ pada dokumen $j$ di dalam kelas $k . t f_{t_{i}, d_{j}}$ adalah jumlah term $i$ di dalam dokumen $j$. $D$ adalah jumlah seluruh dokumen. $d f_{\left(t_{i}\right)}$ adalah jumlah dokumen yang mengandung term $i$. $C$ adalah jumlah seluruh Kelas. $C S_{\delta}\left(t_{i}\right)$ adalah kepadatan ruang kelas terhadap term $i$.

\section{TF-IDF-ICS $\delta$ F-IHS $\delta$ F}

Term Frequency Inverse Document Frequency Inverse Class Space Density Frequency Inverse Hadith Space Density Frequency (TF-IDF-ICS $\delta$ F$\left.\mathrm{IHS}_{\delta} \mathrm{F}\right)$ adalah metode term weighting pengembangan dari TF-IDF-ICS $S_{\delta}$. Jika $I \mathrm{CS}_{\delta} \mathrm{F}$ memperhatikan kepadatan ruang kelas terhadap suatu term, maka $I H S_{\delta} F$ lebih memperhatikan kepadatan ruang Hadis terhadap suatu term. Kepadatan ruang Hadis dihitung untuk mengetahui seberapa besar bobot term jika dihitung pula kelangkaan term tersebut dari keseluruhan Hadis. Semakin term tersebut jarang muncul pada banyak Hadis, maka term tersebut memiliki nilai invers yang tinggi. Kemudian Proses pertama dalam perhitungan $\quad \mathrm{IHS}_{\delta} \mathrm{F}$ adalah menghitung kepadatan kelas terlebih dahulu seperti pada Persamaan (3). Selanjutnya, hasil dari kepadatan kelas terhadap term $i$ dijumlahkan untuk mendapatkan kepadatan Hadis terhadap term $i$ seperti pada persamaan (7).

$H_{\delta}\left(t_{i}\right)=\sum_{c_{k}}^{h_{l}} C_{\delta}\left(t_{i}\right)$

dimana, $H_{\delta}\left(t_{i}\right)$ adalah kepadatan Hadis terhadap term i. $C_{\delta}\left(t_{i}\right)$ adalah kepadatan kelas terhadap term i. $c_{k}$ adalah kelas $(k=1,2, \ldots, m)$. $h_{l}$ adalah hadis $(l=1,2, \ldots, 9)$. Kepadatan kelas $\left(\mathrm{C}_{\delta}\right)$ dengan kepadatan Hadis $\left(\mathrm{H}_{\delta}\right)$ sangatlah berbeda, $C_{\delta}$ menghitung seberapa besar kepadatan kemunculan term pada kelas tertentu dengan melakukan perbandingan jumlah dokumen yang memiliki term pada kelas tertentu dibanding jumlah dokumen keseluruhan pada kelas tertentu sedangkan $\mathrm{H}_{\delta}$ menghitung seberapa besar kepadatan kemunculan term pada Hadis tertentu dengan melakukan penjumlahan kepadatan kelas sebanyak kelas yang ada pada Hadis tertentu. Kepadatan hadis terhadap term $i$ dijumlahkan untuk mendapatkan kepadatan ruang hadis terhadap term $i$ seperti pada persamaan (8).

$H S_{\delta}\left(t_{i}\right)=\sum_{h_{l}} H_{\delta}\left(t_{i}\right)$

dimana, $H S_{\delta}\left(t_{i}\right)$ adalah kepadatan ruang hadis terhadap term $i . H_{\delta}\left(t_{i}\right)$ adalah kepadatan Hadis terhadap term $i . h_{l}$ adalah hadis $(l=1$, $2, \ldots, 9)$. Kepadatan ruang kelas $\left(\mathrm{CS}_{\delta}\right)$ berbeda 
dengan kepadatan ruang Hadis $\left(\mathrm{HS}_{\delta}\right), \mathrm{CS}_{\delta}$ menghitung seberapa besar kepadatan kemunculan term pada keseluruhan kelas sedangkan $\mathrm{HS}_{\delta}$ menghitung seberapa besar kepadatan kemunculan term pada keseluruhan Hadis. Selanjutnya hasil kepadatan ruang hadis terhadap term $i$ dilakukan inverse untuk mengetahui tingkat kelangkaan term terhadap ruang hadis seperti pada persamaan (9)

$I H S_{\delta} F\left(t_{i}\right)=\log \left(\frac{H}{H S_{\delta}\left(t_{i}\right)}\right)$

$I H S_{\delta} F\left(t_{i}\right)$ adalah inverse kepadatan ruang hadis terhadap term i. $H$ adalah jumlah keseluruhan hadis. $H S_{\delta}\left(t_{i}\right)$ adalah kepadatan ruang hadis terhadap term $i$. Selanjutnya hasil inverse dilakukan perkalian dengan persamaan (6) untuk mengetahui bobot term yang memperhatikan kepadatan ruang kelas dan juga kepadatan ruang hadis seperti pada persamaan (10).

$$
\begin{aligned}
W_{T F * I D F * I C S_{\delta} F * I H S_{\delta} F\left(t_{i}, d_{j}, c_{k}, h_{l}\right)} \\
=t f_{t_{i}, d_{j}} \times\left(1+\log \frac{D}{d f_{\left(t_{i}\right)}}\right) \\
\quad \times\left(1+\log \frac{C}{C S_{\delta}\left(t_{i}\right)}\right) \\
\quad \times\left(1+\log \left(\frac{H}{H S_{\delta}\left(t_{i}\right)}\right)\right)
\end{aligned}
$$

dimana, $\quad W_{T F * I D F * I C S_{\delta} F * I H S_{\delta} F\left(t_{i}, d_{j}, c_{k}, h_{l}\right)}$ adalah bobot term $i$ pada dokumen $j$ di dalam kelas $k$ pada hadis $l$. $t f_{t_{i}, d_{j}}$ adalah jumlah term $i$ di dalam dokumen $j$. $D$ adalah jumlah seluruh dokumen. $d f_{\left(t_{i}\right)}$ adalah jumlah dokumen yang mengandung term $i$. $C$ adalah jumlah seluruh Kelas. $C S_{\delta}\left(t_{i}\right)$ adalah kepadatan ruang kelas terhadap term $i$. $H$ adalah jumlah keseluruhan hadis. $H S_{\delta}\left(t_{i}\right)$ adalah kepadatan ruang hadis terhadap term $i$. Hasil pembobotan term dengan memperhatikan kepadatan ruang kelas dan kepadatan ruang hadis ini memberikan nilai yang lebih tinggi terhadap term yang langka pada kelas dan hadis, dan memberikan nilai yang rendah pada term yang jarang muncul. Inverse kepadatan ruang kelas dan ruang hadis ini tetap dikalikan dengan banyaknya term tersebut muncul pada tiap dokumen, sehingga jika term tersebut muncul sangat banyak di dalam suatu dokumen maka bobot term tersebut tetap tinggi. Karena umumnya topik dari sebuah dokumen lebih sering disebutkan di dalam dokumen tersebut. Nilai inverse kepadatan ruang kelas dan ruang hadis ini digunakan untuk menyeleksi term yang terlalu banyak muncul di keseluruhan kelas dan keseluruhan hadis.

\section{Naive Bayes}

Naive Bayes adalah salah satu algoritma klasifikasi formal tertua, dan banyak digunakan algoritma klasifikasi. Dalam model Bayesian, asumsi didasarkan pada probabilitas sebelum dan sesudah. Menemukan probabilitas dari jenis dokumen tertentu, $d_{j}$ anggota $C$ hanya dapat didasarkan pada $t_{i}$ observasi (Azalia, Bijaksana, \& Huda, 2019) .

\section{Support Vector Machine (SVM)}

Pada pendekatan machine learning, Support Vector Machine (SVM) dianggap sebagai salah satu algoritma yang paling kuat dan akurat (Ren \& Sohrab, 2013). Berbeda dengan strategi jaringan saraf yang hanya mencari hyperplane pemisah antara kelas, SVM mencoba menemukan hyperplane terbaik di ruang input (Yusup, Bijaksana, \& Huda, 2019).

\section{HASIL DAN PEMBAHASAN}

Bagian ini akan memaparkan dataset yang digunakan, skenario uji coba, dan hasil uji coba.

\section{Dataset}

Pengumpulan data dilakukan dengan cara melakukan crawl menggunakan aplikasi crawler yang terdapat pada website https://www.octoparse.com/. Proses pengambilan dilakukan dengan menganalisa beberapa alamat website yang akan dijaring kumpulan Hadisnya dari website https://tafsirq.com/. Hadis yang digunakan merupakan hadis dari 9 Imam, yaitu:

- Shahih Bukhari : https://tafsirq.com/hadits/bukhari

- Shahih Muslim : https://tafsirq.com/hadits/muslim

- Sunan Abu Dawud: https://tafsirq.com/hadits/abu-daud

- Sunan at-Turmudzi : https://tafsirq.com/hadits/tirmidzi

- Sunan an-Nasa'i : https://tafsirq.com/hadits/nasai 
178 | Ni'mah, A.T., \& Arifin, A.Z. Perbandingan Metode Term Weighting Terhadap Hasil Klasifikasi Teks ...

- Sunan Ibnu Majah :

https://tafsirq.com/hadits/ibnu-majah

- Musnad Ahmad:

https://tafsirq.com/hadits/ahmad

- Muwatta Malik :

https://tafsirq.com/hadits/malik

- Sunan Darimi :

https://tafsirq.com/hadits/darimi

Masing-masing jumlah Hadis yang digunakan pada setiap kitab, yaitu: Sunan Abu Dawud sebanyak 4419 hadis, Musnad Ahmad sebanyak 4305 hadis, Shahih Bukhari sebanyak 6638 hadis, Sunan Darimi sebanyak 2949 hadis, Sunan Ibnu Majah sebanyak 4285 hadis, Muwatta Malik sebanyak 1587 hadis, Shahih Muslim sebanyak 4930 hadis, Sunan an-Nasa'i sebanyak 5364 hadis, dan Sunan at-Turmudzi sebanyak 3625 hadis. Perincian jumlah hadis yang digunakan dapat dilihat pada Tabel 1. Total dokumen yang diolah di dalam penelitian ini adalah 38102 dokumen dengan 370 kategori dan 9 Kitab Hadis.

Sebuah dokumen di dalam Hadis, memiliki 2 macam isi yaitu: Sanad dan Matan (Azmi et al., 2019). Sanad adalah riwayat, Matan adalah isi inti atau redaksi dari sebuah dokumen Hadis. Penelitian ini hanya menggunakan Matan saja.

Cara memperoleh Matan adalah dengan melakukan penghapusan manual Sanad dari setiap dokumen Hadis. Contoh dokumen Hadis asli dengan disertai Sanad dan dokumen Hadis yang telah dihapus Sanadnya hanya berisi Matan saja dapat dilihat pada Gambar 1.

\section{Pengujian Kinerja}

Uji coba adalah tahapan di mana melakukan pengujian terhadap kesiapan sistem. Uji coba pada penelitian ini menggunakan Confusion

Tabel 1. Rincian Jumlah Dokumen dalam Kitab Hadis

\begin{tabular}{ccc}
\hline Hadis & $\begin{array}{c}\text { Jumlah } \\
\text { Dokumen }\end{array}$ & $\begin{array}{c}\text { Jumlah } \\
\text { Kategori }\end{array}$ \\
\hline Bukhari & 6638 & 77 kategori \\
Muslim & 4930 & 56 kategori \\
Dawud & 4419 & 35 kategori \\
Turmudzi & 3625 & 49 kategori \\
Nasa'i & 5364 & 51 kategori \\
Ibnu Majah & 4285 & 32 kategori \\
Ahmad & 4305 & 14 kategori \\
Malik & 1587 & 32 kategori \\
Darimi & 2949 & 24 kategori \\
\hline
\end{tabular}

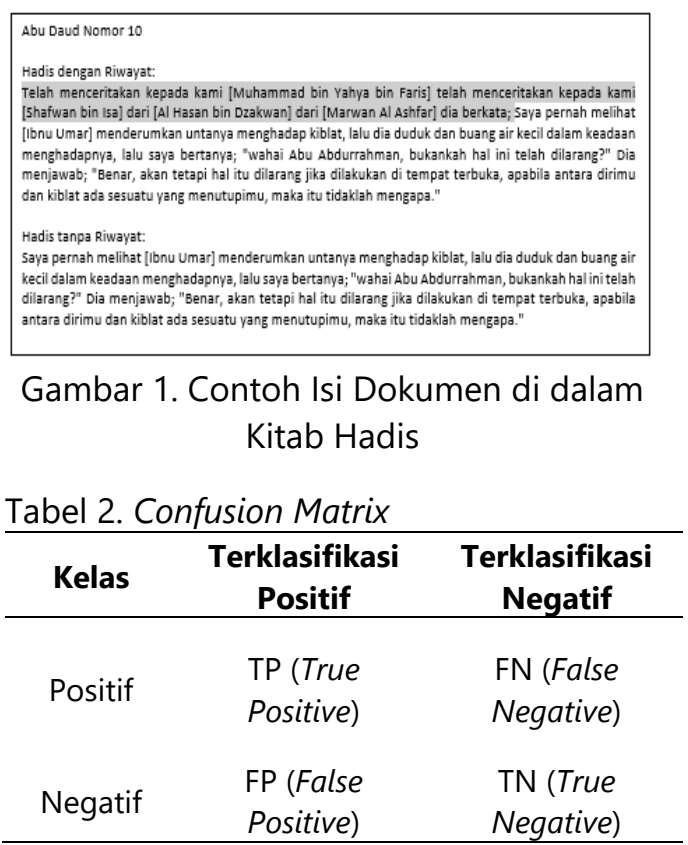

matrix. Confusion matrix merupakan salah satu metode yang dapat digunakan untuk mengukur kinerja suatu metode klasifikasi.

Keakuratan sistem diukur dengan confusion matrix, terdapat 4 (empat) pengukuran hasil klasifikasi. Keempat pengukuran tersebut adalah False Positive (FP), False Negative (FN), True Positive (TP), dan True Negative (TN). Nilai True Negative (TN) adalah data negatif yang terdeteksi sebagai data negatif.

False Positive (FP) adalah nilai dari data negatif yang terdeteksi menjadi data positif. True Positive (TP) adalah data positif yang terdeteksi menjadi data positif. False Negative (FN) adalah kebalikan dari True Positive yaitu data positif yang terdeteksi menjadi data negatif. Tabel Confusion Matrix dapat dilihat pada Tabel 2.

\section{Skenario Uji Coba}

Uji coba adalah tahapan di mana melakukan pengujian terhadap kesiapan sistem. Uji coba pada penelitian ini menggunakan Confusion matrix. Confusion matrix merupakan salah satu metode yang dapat digunakan untuk mengukur kinerja suatu metode klasifikasi. Skenario uji coba terdiri dari 2, yaitu:

1. Perbandingan Hasil Rata-rata Precission, Recall, F1-Score, dan Accuracy pada classifier Naive Bayes

2. Perbandingan Hasil Rata-rata Precission, Recall, F1-Score, dan Accuracy pada classifier SVM 


\section{Hasil Uji Coba}

Hasil uji coba sesuai dengan skenario uji coba pada bab sebelumnya dipaparkan pada Tabel 3 dan 4. Tabel tersebut merangkum seberapa besar perbandingan hasil klasifikasi dari 4 term weighting yang digunakan di dalam penelitian ini. Dari hasil rangkuman terebut disebutkan bahwa metode TF-IDF dengan mesin klasifikasi Naive Bayes mendapatkan hasil yaitu Precission sebesar $82 \%$, Recall sebesar $72 \%$, F1-Score sebesar 75\%, dan Accuracy sebesar $81 \%$. TF-IDF-ICF dengan mesin klasifikasi Naive Bayes mendapatkan hasil yaitu Precission sebesar 90\%, Recall sebesar 93\%, F1-Score sebesar 91\%, dan Accuracy sebesar 83\%. TF-IDF-ICS $\delta$ F dengan mesin klasifikasi Naive Bayes mendapatkan hasil.

Precission sebesar 91\%, Recall sebesar $86 \%$, F1-Score sebesar 88\%, dan Accuracy sebesar 93\%. TF-IDF-ICS $\delta$ F-IHS $S_{\delta} \mathrm{F}$ dengan mesin klasifikasi Naive Bayes mendapatkan hasil yaitu Precission sebesar 96\%, Recall sebesar 93\%, F1-Score sebesar 94\%, dan Accuracy sebesar $95 \%$. TF-IDF dengan mesin klasifikasi SVM mendapatkan hasil yaitu Precission sebesar $80 \%$, Recall sebesar 65\%, F1-Score sebesar $70 \%$, dan Accuracy sebesar 76\%. TFIDF-ICF dengan mesin klasifikasi Naive Bayes mendapatkan hasil yaitu Precission sebesar $82 \%$, Recall sebesar 70\%, F1-Score sebesar 74\%, dan Accuracy sebesar 82\%. TF-IDF-ICS ${ }_{\delta} \mathrm{F}$ dengan mesin klasifikasi Naive Bayes mendapatkan hasil yaitu Precission sebesar $88 \%$, Recall sebesar $80 \%$, F1-Score sebesar $83 \%$, dan Accuracy sebesar $88 \%$. TF-IDF-ICS $\delta$ F$\mathrm{IHS}_{\delta} \mathrm{F}$ dengan mesin klasifikasi Naive Bayes mendapatkan hasil yaitu Precission sebesar 90\%, Recall sebesar 93\%, F1-Score sebesar 92\%, dan Accuracy sebesar $83 \%$. Dari hasil tersebut dapat terlihat bahwa hasil terbaik

Tabel 3. Hasil Uji Coba pada Mesin Klasifikasi Naive Bayes

\begin{tabular}{ccccc}
\hline $\begin{array}{c}\text { Confusion } \\
\text { Matrix }\end{array}$ & $\begin{array}{c}\text { TF- } \\
\text { IDF }\end{array}$ & $\begin{array}{c}\text { TF- } \\
\text { IDF- } \\
\text { ICF }\end{array}$ & $\begin{array}{c}\text { TF- } \\
\text { IDF- } \\
\text { ICS }\end{array}$ & $\begin{array}{c}\text { TF- } \\
\text { IDF- }\end{array}$ \\
$\begin{array}{cccc}\text { ICS } \\
\text { IHS- }_{\delta} \text { F }\end{array}$ \\
\hline Precission & 0,82 & 0,90 & 0,91 & $\mathbf{0 , 9 6}$ \\
Recall & 0,72 & $\mathbf{0 , 9 3}$ & 0,86 & $\mathbf{0 , 9 3}$ \\
F1-Score & 0,75 & 0,91 & 0,88 & $\mathbf{0 , 9 4}$ \\
Accuracy & 0,81 & 0,83 & 0,93 & $\mathbf{0 , 9 5}$ \\
\hline
\end{tabular}

Tabel 4. Hasil Uji Coba pada Mesin Klasifikasi Support Vector Machine

\begin{tabular}{|c|c|c|c|c|}
\hline $\begin{array}{c}\text { Confusion } \\
\text { Matrix }\end{array}$ & $\begin{array}{l}\text { TF- } \\
\text { IDF }\end{array}$ & $\begin{array}{c}\text { TF- } \\
\text { IDF- } \\
\text { ICF }\end{array}$ & $\begin{array}{c}\text { TF- } \\
\text { IDF- } \\
\text { ICS } S_{\delta}\end{array}$ & $\begin{array}{c}\text { TF- } \\
\text { IDF- } \\
\text { ICS } \text { I F- } \\
\text { IHS }\end{array}$ \\
\hline Precission & 0,80 & 0,82 & 0,88 & 0,90 \\
\hline Recall & 0,65 & 0,70 & 0,80 & 0,93 \\
\hline F1-Score & 0,70 & 0,74 & 0,83 & 0,92 \\
\hline Accuracy & 0,76 & 0,82 & 0,88 & 0,83 \\
\hline
\end{tabular}

didapatkan dari term weighting TF-IDF-ICS $\delta$ F$\mathrm{IHS} \delta_{\delta} \mathrm{F}$ untuk keseluruhan mesin klasifikasi. TFIDF-ICS $\delta$ F-IHS $S_{\delta} \mathrm{F}$ mendapatkan hasil terbaik pada mesin klasifikasi Naive Bayes.

\section{KESIMPULAN}

Kesimpulan dari penelitian ini adalah metode term weighting $\mathrm{TF}-\mathrm{IDF}-\mathrm{ICS} \mathrm{S}_{\delta} \mathrm{F}-\mathrm{IHS} \mathrm{S}_{\delta} \mathrm{F}$ telah mampu memberikan hasil terbaik dan mengungguli term weighting lain di dalam penerapannya terhadap mesin klasifikasi dengan dataset terjemahan 9 Kitab Hadis. Hasil yang diperoleh pada mesin klasifikasi Naive Bayes adalah Precission sebesar 90\%, Recall sebesar 93\%, F1-Score sebesar 92\%, dan Accuracy sebesar $83 \%$.

Saran untuk penelitian selanjutnya adalah melakukan penelitian terhadap perbandingan dengan lebih banyak term weighting, mesin klasifikasi, dan penerapan terhadap dataset selain Kitab Hadis.

\section{DAFTAR PUSTAKA}

Adriani, M., Nazief, B., Asian, J., Tahaghoghi, S. M. M., and Williams, H. E. (2007). Stemming Indonesian. ACM J. Educ. Resour. Comput. 6, 4, 38(December), 307-314. https://doi.org/10.1145/1316457.13 16459

Andita Dwiyoga Tahitoe, D. P. (2010). Implementasi Modifikasi Enhanced Confix Stripping Stemmer Untuk Bahasa Indonesia Dengan Metode Corpus Based Stemming. Jurnal Ilmiah, 1-15.

Arifin, Z. (2013). Studi Kitab Hadis. In Srudi. https://doi.org/10.1364/OL.36.00012 7 
Azalia, F. Y., Bijaksana, M. A., \& Huda, A. F. (2019). Name indexing in Indonesian translation of hadith using named entity recognition with naïve bayes classifier. Procedia Computer Science, 157, 142-149. https://doi.org/10.1016/j.procs.2019 .08 .151

Azmi, A. M., Al-Qabbany, A. O., \& Hussain, A. (2019). Computational and natural language processing based studies of hadith literature: a survey. Artificial Intelligence Review, 52(2), 1369-1414.

https://doi.org/10.1007/s10462-

019-09692-w

Deposit, C., Shi, L. I., \& Jianping, C. (2018). Prospecting Information Extraction by Text Mining Based on Convolutional Neural Networks - A Case Study of the Lala. IEEE Access, 6, 52286-52297.

https://doi.org/10.1109/ACCESS.201 8.2870203

Dogan, T., \& Uysal, A. K. (2019). Improved inverse gravity moment term weighting for text classification. Expert Systems with Applications, 130, 45-59. https://doi.org/10.1016/j.eswa.2019. 04.015

Kim, S. W., \& Gil, J. M. (2019). Research paper classification systems based on TF IDF and LDA schemes. HumanCentric Computing and Information Sciences. https://doi.org/10.1186/s13673019-0192-7

Mahendra. (2007). Enhanced Confix Stripping Stemmer And Ants Algoritm For Classifying News Document in Representation of Textual. Technology, (April), 149-158.

Ren, F., \& Sohrab, M. G. (2013). Class-indexingbased term weighting for automatic text classification. 236, 109-125.

Rostam, N. A. P., \& Malim, N. H. A. H. (2019). Text categorisation in Quran and
Hadith: Overcoming the interrelation challenges using machine learning and term weighting. Journal of King Saud University - Computer and Information Sciences, (xxxx). https://doi.org/10.1016/j.jksuci.2019 .03 .007

Sabbah, T., Selamat, A., Selamat, M. H., Al-Anzi, F. S., Viedma, E. H., Krejcar, O., \& Fujita, H. (2017). Modified frequency-based term weighting schemes for text classification. Applied Soft Computing Journal, 58, 193-206.

https://doi.org/10.1016/j.asoc.2017. 04.069

Saloot, M. A., Idris, N., Mahmud, R., Ja'afar, S., Thorleuchter, D., \& Gani, A. (2016). Hadith data mining and classification: a comparative analysis. Artificial Intelligence Review, 46(1), 113-128.

https://doi.org/10.1007/s10462016-9458-x

Tala, F. Z. (2003). A Study of Stemming Effects on Information Retrieval in Bahasa Indonesia. M.Sc. Thesis, Appendix D, pp, 39-46.

Uysal, A. K., \& Gunal, S. (2014). The impact of preprocessing on text classification. Information Processing and Management, 50(1), 104-112. https://doi.org/10.1016/j.ipm.2013.0 8.006

Yang, K., Cai, Y., Leung, H. Fung, Lau, R. Y. K., \& Li, Q. (2019). ITWF: A framework to apply term weighting schemes in topic model. Neurocomputing, 350, 248-260. https://doi.org/10.1016/j.neucom.20 19.02.048

Yusup, F. A., Bijaksana, M. A., \& Huda, A. F. (2019). Narrator's name recognition with support vector machine for indexing Indonesian hadith translations. Procedia Computer Science, 157, 191-198. https://doi.org/10.1016/j.procs.2019 .08 .157 